\title{
THE EFFECT OF BOARD OF COMMISSIONERS, AUDIT COMMITTEE, COMPANY SIZE, AND CAPITAL STRUCTURE ON AGENCY COSTS: INDONESIA PERSPECTIVE
}

\author{
Deo Dio Du Simanjuntak*1), Judith T. Gallena Sinaga ${ }^{2)}$ \\ Universitas Advent Indonesia ${ }^{1,2)}$ \\ deosimanjuntak1808@gmail.com ${ }^{1)}$,judith.sinaga@unai.edu ${ }^{2)}$
}

\begin{abstract}
This research was conducted to examine whether agency cost can be influenced by the board of commissioners, audit committee, company size, and capital structure. This seeks to contribute to the literature of factors influencing agency cost in Indonesia. Agency cost exists because of some assymetircal information and conflicts between principal and agent. The study used descriptive method of which purposive sampling method was used in sample selection. The samples were selected from the top 100 largest wealth-creators companies in 2019 in Indonesia. Using the wealth-creators companies as the samples makes this research a unique one. The classical assumption test was conducted to check the relationship between variables. Data gathered were analyzed and interpreted using multiple regression analysisof which t-test and F-test were considered. The study revealed that agency cost was simultaneously influenced by the board of commissioners, audit committee, company size, and capital structure. Partially, this study found that board of commissioners and company size have siginificant influence on agency cost, while audit committee and capital structure have no influence on agency cost. The findings indicate that there are several factors that influences agency cost. Thus, agency cost can be minimized by proper monitoring by the presence of board of commissioner; while company size and capital structure trigger agency costs.
\end{abstract}

Keywords: commissioners, wealth-creators, audit committee, companys, Size, audit fee

*Corresponding author:

Email: deosimanjuntak1808@gmail.com

DOI: https://doi.org/10.33369/j.akuntansi.11.2.149-162

\section{INTRODUCTION}

Achieving high profit is the company's goal, management tries and competes to be the best in quality and huge in quantity. Companies use various ways to achieve their main goals. Various policies and actions taken by management to achieve profit are not always in line with the wishes of the owner or the principal. As what happened to one of the airlines in our country, namely Garuda Indonesia, where, the company management made efforts to enhance the quality of the company by manipulating its financial statements in 2018. This fraud was discovered by 2 boards of commissioners of Garuda Indonesia at that time because the financial statements were not following accounting standards (Giri Hartomo, 2018). Another case of fraud happned in the company PT Kimia Farma Tbk, where its 2010 financial statements were suspected by the Ministry of State-Owned Enterprises and Capital Advisory Board (Bapepam) to contain engineering elements so that they had to be sanctioned along with the auditors (Yura Syahrul, 2003). From the above phenomenon, we can see that there is a conflict of interest in company management that is not in line with the interests of the principal. This phenomenon has been explained in agency theory by Jensen and Meckling where 3 things cause agency conflicts, namely differences in the interests of principals and agents, lack of supervision by principals, and information asymmetry (Jensen \& Meckling, 1976). For mitigating this conflict, costly supervision is needed which is called agency cost. The relationship between the two entities occurs when the shareholders (principal) hire a manager (agent) and give him the authority and responsibility to make decisions which is called agency theory (Afriani, 2017).

Lack of supervision by principals of management actions results in high opportunities for management to prioritize their interests. In monitoring the performance of management, the company requires the role of the board of commissioners to oversee every performance and 
policy by company management that has been described in Laws of Limited Liability Company (Undang-Undang Perseroan Terbatas) no 40 of 207 article 108 Financial Services Authorithy (Otoritas Jasa Keuangan Republik Indonesia, 2007). A facultative audit committee is formed by the board of commissioners to assist with the duties and responsibilities of overseeing management actions. Recommending public accountants for companies is a critical and important task by the audit committee which is also described in Financial Servies Authority (Otoritas Jasa Keuangan) regulations no. 55 of 2015 Capital Market Supervisory Agency and Financial Institution (Badan Pengawas Pasar Modal dan Lembaga Keuangan, 2012). This task is one of the important tasks because the chosen public accountant must have high independence which will give birth to an honest audit opinion.

Several researchers have examined the composition of the board of commissioners against agency costs such as research by Pratiwi (2017), and Sitompul (2019), that found the board of commissioners with a small size would result in effective supervision that affected the audit fee, it was also explained the difficulty of communication if the composition of the board of commissioners was too large causing the agency cost to be higher, whereas Surjawati, Rossyati, \& Widowati (2015), who found that there was no influence of the board of commissioners on agency cost because the company's management had gone well so that the agency cost to be borne by the company was not influenced by the composition of the board of commissioners.

The size of a company is considered capable of influencing agency cost. The size of a company is valued based on assets, sales, and market capitalization. According to Septiawan \& Wirawati (2016), the bigger a company is, the level of moral hazard occurs where managers use incentives to prioritize their interests that are not in the work contract. Research by Annisata dan Fitriany (cite in Irwansyah, Lestari, \& Adam, 2020), revealed the results that in large companies, management's actions are considered to be more prudent than the management of small-sized companies, which is characterized by having a significant effect on agency cost, but according to Immanuela (2014), the agency cost of the company itself is not influenced by the size of the company, which is explained by large companies that do not have difficulties in funding which encourages company management to not be careful in using discretionary expense.

The capital structure consists of debt and equity, a company can run or operate if it has a source of funding or capital. According to Zheng (2013), the existence of a good capital structure can minimize agency conflicts between principals and agents, so it can be said that the use of a good capital structure can reduce agency costs. The use of debt in the company is alleged to reduce agency costs, with the increase in corporate debt, company managers are required to pay off debts with free cash flow. According to Jaelani (2017), the use of debt can minimize the manager's actions on unnecessary expenses so that the manager's self-interest can be overcome. Theoretically, the more the board of commissioners, the company's agency cost will decrease to save more on these expenses. Similarly, an increased audit committee composition can reduce the company's agency costs because of the audit committee's role as a tool for assisting the board of commissioners in overseeing the performance of company management. Firm size and capital structure are also felt to affect the company's agency costs theoretically, where large companies have a high level of complexity compared to small companies, which requires more effort for public accountants to audit the company, allowing companies to spend more agency costs. than small companies. Debt is one element of the capital structure where with debt, management is more careful in using company funds for their personal interests to reduce agency costs to monitor their actions. Researchers want to develop this research through previous studies by adding capital structure variables rarely studied and choosing audit fees to measure agency costs, which are rarely used in previous studies. The purpose of this research is to existence of a phenomenon or agency case in Indonesia and 
differences in the results of previous studies have encouraged researchers to examine the effects of all independent variables in this study on agency cost. So based on the background explanation above, this study will examine whether agency cost through audit fees can be influenced by the board of commissioners, audit committee, company size, and capital structure.

According to Jensen \& Meckling (1976), agency cost is an expense in the form of fees charged to the principal for overseeing the actions of an agent or manager which is divided into 3 types, namely, bonding costs, monitoring costs, and residual loss. This study measures the dependent variable agency cost with an audit fee where the audit fee is one component of the agency cost from the type of monitoring cost. Due to the difference in interests between management and the principal, it causes a decrease in the welfare of the principal, resulting in what is called residual loss (Jensen \& Meckling, 1976). Agency cost, which is proxied by the company's audit fee, is expected to be able to unify management and principals based on their interests and priorities so that the company's management will act according to the wishes and interests of the principals as reflected in the company's financial statements. According to Destriana (2015), agency theory describes company management as not an entity that is fair and wise in making decisions because management will act with full awareness for their interests which does not prosper the principal. Therefore, good quality of supervision needs to be given to company management, where this supervision will be carried out by an appointed or selected public accountant who will cost according to the complexity of the company which is called an audit fee which is included in the agency cost category, namely monitoring cost.

The audit fee is part of agency cost which is included in the type of cost monitoring. Audit fee according to Sukrisno (2012), is a form of reciprocity for services in the form of fees provided by clients, namely companies to auditors who are public accountants. This audit fee functions to supervise the actions of company management on their behalf through an examination of the financial statements. According to DeAngelo (1981), an audit fee is a form of reciprocal cost that is measured on several aspects of the audit work which can be said to be varied costs. Low audit fees given to auditors may lead to acts of disobedience to policies or code of ethics as a public accountant (Cristansy \& Ardiati, 2016). Therefore, in determining fees, auditors need to pay attention to many aspects such as complexity, the amount of time given by the company that has been listed in IAPI Decree No. 24 of 2008. To reduce agency conflict, monitoring of management actions is needed, by issuing a high audit fee, the quality of the audit provided to supervise management actions through financial reports will be higher (Hapsari \& Laksito, 2013).

The difference in interests that is a problem between management and principals can be reduced by the existence of corporate governance, of which the board of commissioners is a part. One of the functions of the board of commissioners is the monitoring function in which the board of commissioners ensures, supervises, and directs the company's management to act to meet the welfare of the principals, namely improving company performance, and eliminating agency problems between principals and management, the role of the Board of Commissioners is also expected to reduce agency cost (Wijayati, 2015). Research by Sitompul (2019), found that the audit fee increases with the increase in the composition of the board of commissioners, which is indicated by the audit fee being significantly influenced by the size of the board of commissioners which is similar to research by Chandra (2015), which shows that the audit fee results are positively influenced by the size of the board of commissioners. The board of commissioners is measured by the number of the company's commissioners, and the following hypothesis is concluded:

$H_{1}$ : The composition of the company's board of commissioners has a significant effect on agency cost. 
According to Badan Pengawas Pasar Modal dan Lembaga Keuangan (2012), in assisting and maximizing its supervisory function, the board of commissioners establishes a facultative audit committee which is fully explained through the Decision of the Chairman of BAPEPAM no 29 of 2004. According to research by Ayu \& Septiani (2018), where the researcher argues that an audit committee with a large composition will demand high audit quality so that the audit fee will increase, which is indicated by the significant effect of the audit committee on the audit fee. A high level of independence and a qualified KAP reputation and reputation is the choice of the audit committee as the company's public accountant which is expected to have good performance by the auditors which will affect the audit fee borne by the company. According to Nugroho (2017), the high composition of the audit content makes the audit fee even higher because it can maximize supervision of the company management and also demands a high-quality audit by the appointed public accountant. The audit committee is measured by the composition of the audit committee of each company and based on the explanation above, the resulting hypothesis is as follows:

$\mathrm{H}_{2}$ : The composition of the company's audit committee has a significant effect on agency cost

The size or size of a company can be seen from the company's total assets which are considered to affect agency cost as measured by the company's audit fee. Firm size is proxied using the natural logarithm of total assets as in the same study by Hasan (2017), where the researchers found that company size influences audit fees. According to Wiratmaja \& Haryani (2014), large companies will make more transactions and the high level of company complexity causes the need for more time to be audited by public accountants than small companies so that it will affect the audit fees charged by the company. In Ikatan Akuntan Publik Indonesia (2016), the audit fee will relate to the timing of the audit and the composition of the staff conducting the audit. Based on the description above, the following hypothesis can be formulated:

$\mathrm{H}_{3}$ : Firm size has a significant effect on agency cost

A company can operate if it has a source of funding in the form of debt and equity which is included in the capital structure. The existence of debt borne by the company can encourage managers to act in the interests of the principal and if the level of debt of a company is high, the control and supervision by creditors of the company will also be tighter. (Godfrey et al 2010). And with this increased supervision, agency problems can be reduced and agency costs can be reduced (Lastian, 2015). The capital structure will be measured using the Debt to Asset Ratio (DER), which according to Romadhoni \& Sunaryo (2017), this ratio is a reflection of the company's ability to meet its obligations. In Maryam (2018), found the results that capital structure has a significant positive effect on agency cost, which is inversely proportional to research by Pujawati \& Surasni (2019), by showing the result that there is no effect of capital structure on agency cost, which means that the use of debt as measured by DER does not have a major impact on reducing agency cost. From the explanation above, it can be concluded that the hypothesis is as follows:

$\mathrm{H}_{4}$ : Capital structure has a significant effect on agency cost

So that through the theoretical study above, this research is expected to be able to answer the effect of all the above independent variables on agency cost. Where according to research the audit fee can increase along with the increasing composition of the board of commissioners which demands a good audit quality. The company audit committee is expected to be able to minimize agency costs through the supervisory function which is the main task of the audit committee which encourages management to act in the interests of the principal. The size of the company is also expected to be able to influence the agency cost which is proxied by using 
an audit fee where a large company has a high level of difficulty and complexity which requires considerable time and effort to carry out an audit which will affect the audit fee that must be borne. And the capital structure variable is also expected to be able to influence the company's agency cost where debt and equity are a type of capital structure that a company uses to fund the company in carrying out its performance so that company management is expected to be able to be careful in using this capital so that the agency cost borne by the company can be reduced. By these explanation, it can be concluded that the hypothesis is as follows:

$\mathrm{H}_{5}$ : Board of commisioners, audit committee, company size and capital structure simultaneously influence agency costs.

The explanation above can be described as a framework of thought as follows:

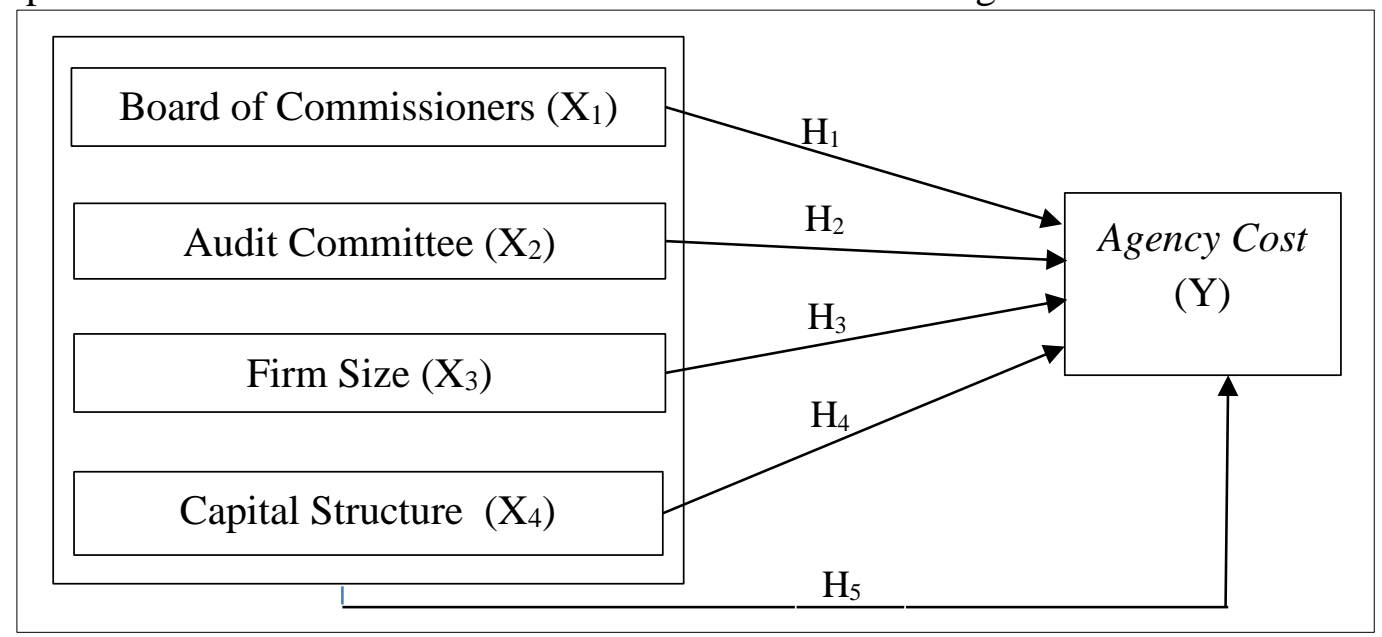

Figure 1. Research Conceptual Framework

\section{RESEARCH METHODOLOGY}

This research adheres to a quantitative research system using descriptive methods. The research object used by the author is the 100 best wealth-creators companies in Indonesia in 2019 as published in SWA Magazine, July 13, 2019 edition, with financial reports and annual reports of research objects through secondary data as instruments. The research data was tested using several data analyzes such as Descriptive statistical test. This study also tested the data using correlation test, classical assumption test, multicollinearity test, determination coefficient test (R-Square), F test, and partial test (t-test) to be processed using SPSS 23 software and the results of this test will be presented in the results and discussion section. The normality test in this study used a histogram graph, normal p-p plot, and one sample k-s. Determination of the research sample using purposive sampling method with the following criteria:

1. The 100 best wealth creators companies in Indonesia in 2019 according to the July 13, 2019 edition of SWA Magazine.

2. Has an annual report of the 100 best wealth creators companies in Indonesia in 2019, which has been audited by the SWA Magazine, July 132019 edition.

3. Include the data needed by researchers in the financial and annual reports of the 100 best wealth creators companies in Indonesia in 2019, according to the July 132019 edition of SWA Magazine.

Table 1- Sample Selection Criteria

\begin{tabular}{lc}
\hline \multicolumn{1}{c}{ Data Criterias } & Number of Samples \\
\hline The 100 best wealth creators companies in Indonesia in 2019 according to the & 100 \\
July 13, 2019 edition of SWA Magazine. &
\end{tabular}


THE EFFECT OF BOARD OF COMMISSIONERS, AUDIT COMMITTEE, COMPANY SIZE, AND

CAPITAL STRUCTURE ON AGENCY COSTS: INDONESIA PERSPECTIVE

Deo Dio Du Simanjuntak and Judith T. Gallena Sinag

\begin{tabular}{lc}
\hline \multicolumn{1}{c}{ Data Criterias } & Number of Samples \\
\hline $\begin{array}{l}\text { Research data companies that upload financial reports on the Indonesia Stock } \\
\text { Exchange }\end{array}$ & 100 \\
\hline $\begin{array}{l}\text { Companies that disclose the data needed by researchers through the sample } \\
\text { companies' annual reports }\end{array}$ & 57 \\
\hline
\end{tabular}

Based on the Table above, it is found that 57 companies selected as samples in this study are publicly listed companies or companies that have been listed on the Indonesia Stock Exchange.

To test the hypothesis, this study produces a regression model as follows:

$A C=\alpha+\beta_{1} B O C+\beta_{2} A C O M+\beta_{3} F I S I+\beta_{4} D E R+e$

With the following explanation:

$\mathrm{AC}=$ Agency Cost

$\mathrm{BOC}=$ Board of Commissioners

$\mathrm{ACOM}=$ Audit Committee

FISI $=$ Firm Size

DER $=$ Capital Structure

Then the results of the data analysis will be explained in the topic of results and discussion.

\section{RESULT AND DISCUSSION}

This study has fifty-seven (57) samples which were gathered from the top 100 wealth creators companies listed in Indonesia Stock Exchange. The following are the descripitive results of the data gathered:

Table 2 - Descriptive Statistical Analysis

\begin{tabular}{lccccc}
\hline \multicolumn{1}{c}{ Variable } & N & Minimum & Maximum & Mean & Std. Deviation \\
\hline Board of Commissioners & 57 & 3 & 10 & 5,34 & 1.78 \\
\hline Audit Committee & 57 & 3 & 5 & 3,42 & 0.63 \\
\hline Firm Size & 57 & 28,69 & 34,33 & 31,11 & 1.33 \\
\hline Capital Structure & 57 & 0,03 & 7,06 & 1,83 & 1,86 \\
\hline Agency Cost & 57 & 19,4 & 24,72 & 21,76 & 1,26 \\
\hline
\end{tabular}

The Table 1 above shows the descriptive analysis (minimum, maximum, mean, and std. deviation) of each variable in the study. The board of commissioners modeled as BOC has an average value of 5.34, audit committee variable is modeled as ACOM has an average value of 3.42 , with a minimum value of 3 which means that all research sample companies have complied with the regulations set with a minimum number of audit committee members as many as 3 people, size of the company with the FISI model has an average value of 31.11, capital structure which is measured and modeled as DER has an average value of 1.83, and the agency cost with the AC model as measured by the audit fee of the research sample companies has an average value of 21.76 . 
Through the histogram graph, it can be seen that the curve tends to be symmetrical so that the data in this study is normally distributed where there is no extreme right or left slope.

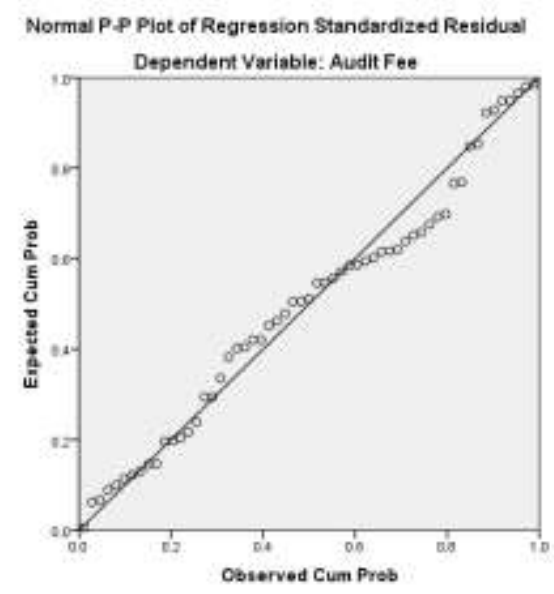

Figure 2. Normal P P Plot

The data processed in this study spread around and follows the direction of the diagonal line so that it meets the assumption of normality.

Table 3. One Sample K S Test

\begin{tabular}{|c|c|c|}
\hline & & Unstandardiz ed Residual \\
\hline $\mathrm{N}$ & & 57 \\
\hline \multirow[t]{2}{*}{ Normal Parameters $^{\mathrm{a}, \mathrm{b}}$} & Mean & .000000 \\
\hline & Std. Deviation & 1.00496348 \\
\hline \multirow[t]{3}{*}{ Most Extreme Differences } & Absolute & .102 \\
\hline & Positive & .102 \\
\hline & Negative & -.065 \\
\hline \multirow{2}{*}{\multicolumn{2}{|c|}{$\begin{array}{l}\text { Test Statistic } \\
\text { Asymp. Sig. (2-talled) }\end{array}$}} & .102 \\
\hline & & $.200^{\mathrm{c.d}}$ \\
\hline $\begin{array}{ll}\text { a. Test distribution is } \\
\text { b. Calculated from d } \\
\text { c. Lilliefors significa } \\
\text { d. This is a lower bou }\end{array}$ & $\begin{array}{l}\text { Jormal } \\
\text { d of the true sign }\end{array}$ & \\
\hline
\end{tabular}

Then the significance value of Asymp. Sig (2 tailed) this research data is greater than 0.05 (Asiymp. Sig (2 tailed)> 0.05) then it fulfills the assumption of normality.

Table 4 - Multicollinearity Test

\begin{tabular}{lcc}
\hline \multicolumn{1}{c}{ Model } & Tolerance & VIF \\
\hline Board of Commissioners & 0,780 & 1,238 \\
\hline Audit Committee & 0,749 & 1,335 \\
\hline Firm Size & 0,738 & 1,355 \\
\hline Capital Structure & 0,731 & 1,369 \\
\hline Dependent Variable: Audit Fee &
\end{tabular}

Based on the results from table 2 of the multicollinearity test, in this study found that the VIF value of the four independent variables is less than 10 (VIF <10) and the tolerance value is greater than 0.1 (tolerance $>0.1$ ), so there is no multicollinearity. 
THE EFFECT OF BOARD OF COMMISSIONERS, AUDIT COMMITTEE, COMPANY SIZE, AND

CAPITAL STRUCTURE ON AGENCY COSTS: INDONESIA PERSPECTIVE

Deo Dio Du Simanjuntak and Judith T. Gallena Sinag

Table 5 - Autocorrelation Test Durbin Watson

\begin{tabular}{ccccc}
\hline $\mathrm{R}$ & R Square & $\begin{array}{c}\text { Adjusted R } \\
\text { Square }\end{array}$ & $\begin{array}{c}\text { Std. Error of the } \\
\text { Estimate }\end{array}$ & Durbin-Watson \\
\hline $0.610^{\mathrm{a}}$ & 0,373 & 0,324 & 1,04290 & 1,990 \\
\hline
\end{tabular}

The last classic assumption test is the autocorrelation test using Durbin Watson's analysis. It can be said that there is no autocorrelation if the value of DW> DU and (4-DW)> DU. From the tabel 3, the data has been processed, the resulting DW value is 1.990 , with a DU value in the table of 1.7253 so that the conditions for not autocorrelation are met where the DW value (1.990)> DU (1.7253) and the value of 4-DW (4 - 1.990) > DU (1.7253).

\section{The effect of board commissioner on agency costs}

Board commissioners (BOC) play a vital role in mininimzing agency costs. BOC's supervision implies a proper control in monitoring company's activities.

Table 6 - Correlation

\begin{tabular}{|c|c|c|c|c|}
\hline $\mathrm{R}$ & R Square & $\begin{array}{l}\text { Adjusted R } \\
\text { Square }\end{array}$ & $\begin{array}{l}\text { Std. Error of the } \\
\text { Estimate }\end{array}$ & Durbin-Watson \\
\hline 0.473 & 0.223 & 0.209 & 1.05776 & 1.869 \\
\hline \multicolumn{5}{|c|}{ Regression Analysis } \\
\hline & Variable & $\begin{array}{l}\text { Unstandardized } \\
\text { Coefficients (B) }\end{array}$ & \multicolumn{2}{|c|}{$\begin{array}{c}\text { Significance } \\
\text { Value }(\alpha=5 \%)\end{array}$} \\
\hline & Commissioners & 0,311 & \multicolumn{2}{|c|}{0,000} \\
\hline
\end{tabular}

Based on the Table above the results of the significant value where partially the board of commissioners can significantly influence agency cost with a value of 0.000 . The agency cost of a company is considered to increase with the increase in the composition of the board of commissioners, which is interpreted as the greater the composition of the board of commissioners of a company, the higher the audit fee will also increase where high audit quality is demanded by the board of commissioners of public accountants and $\mathrm{H}_{1}$ is accepted. With research results that are supported from several previous studies by proprietary research Chandra (2015), and Sitompul (2019), the board of commissioners found and its significant effect on agency cost, which is proxied by the audit fee where the study revealed that the board of commissioners was able to reduce agency costs through the supervision provided to management. Different results are obtained by Gul, Sajid, Razzaq, \& Afzal (2012), where the board of commissioners with a smaller number is considered more effective in reducing agency costs and the supervisory function itself can be carried out more neatly. The same thing is obtained by Fatahillah (2018), where there is a positive influence on agency costs by the board of commissioners so that it can be said that through this study the increasing size of the board of commissioners is not effective in reducing agency costs. This study revealed different results, where the greater the composition of the company's board of commissioners, the company's agency cost also increases, which is indicated by a tendency to lack supervision, monitoring, and control of company activities.

\section{The effect of audit committee on agency costs}

Audit committee members have the right to hire external auditors for lessening assymetric information. 
Table 7 - Correlation

\begin{tabular}{ccccc}
\hline \multirow{2}{*}{$\mathrm{R}$} & R Square & $\begin{array}{c}\text { Adjusted R } \\
\text { Square }\end{array}$ & $\begin{array}{c}\text { Std. Error of the } \\
\text { Estimate }\end{array}$ & Durbin-Watson \\
\hline 0.231 & 0.053 & 0.036 & 1.16794 & 1.840 \\
\hline & \multicolumn{3}{c}{ Regression Analysis } \\
\cline { 2 - 4 } & Variable & $\begin{array}{c}\text { Unstandardized } \\
\text { Coefficients (B) }\end{array}$ & $\begin{array}{c}\text { Significance } \\
\text { Value }(\alpha=5 \%)\end{array}$ \\
\cline { 2 - 4 } & Audit Committee & $-0,385$ & 0,083 \\
\cline { 2 - 4 } & & &
\end{tabular}

By the regression table above, the significance value of audit committee is 0,083 so partially agency cost cannot be influenced by the company's audit committee. In other words, the composition of the audit committee of a company is considered less effective in minimizing the agency cost proxied by the company's audit fee. The high composition of the audit committee does not affect the effectiveness of monitoring financial statements so that it does not require a long audit time, and it does not affect the audit fee, thus $\mathrm{H}_{2}$ is rejected. This research is appropriate and supported by research results according to Pratiwi (2017)); Krisnauli \& Hadiprajitno (2014); Audinia (2017), according to those study, the composition of the audit committee does not have a significant effect, which shows that the company complies with regulatory formalities. Deviant results are obtained by Hastori, Siregar, Sembel, \& Ahmad Maulana (2015), where there is a positive influence of the audit committee on agency costs where the audit committee itself does not have an effective effect on reducing agency costs and it can also be said that ineffective supervision by the audit committee can affect the agency costs issued by the company. This study indicated with the average audit committee of all sample companies of 3.42 , so it indicates the ineffectiveness of the audit committee in carrying out its duties to assist the board of commissioners and this shows the ineffectiveness of the audit committee in carrying out its duties to supervise management activities to assist the board of commissioners so that it does not have a significant effect on auditors' duties and the length of audit time does not affect the audit fees charged.

\section{The effect of company size on agency costs}

Company size is another factor that affects agency costs. Company size is represented by total assets

Table 8 - Correlation

\begin{tabular}{ccccc}
\hline \multirow{2}{*}{$\mathrm{R}$} & R Square & $\begin{array}{c}\text { Adjusted R } \\
\text { Square }\end{array}$ & $\begin{array}{c}\text { Std. Error of the } \\
\text { Estimate }\end{array}$ & Durbin-Watson \\
\hline 0.608 & 0.370 & 0.359 & 0.95250 & 1.977 \\
\hline & \multicolumn{3}{c}{ Regression Analysis } \\
\cline { 2 - 4 } & Variable & $\begin{array}{c}\text { Unstandardized } \\
\text { Coefficients (B) }\end{array}$ & $\begin{array}{c}\text { Significance } \\
\text { Value }(\alpha=5 \%)\end{array}$ \\
\cline { 2 - 4 } & Firm Size & 0,687 & 0,000 \\
\hline
\end{tabular}

The size of a company affects the agency cost. The size of a company is measured by the number of total assets, so the level of complexity of the company's financial statements can be reflected in the size of the company so that the audit fee incurred will be in line with the size of the company so that through the results of this study $\mathrm{H}_{3}$ is accepted. The results of Harahap (2011) research reveal a relationship that has no effect because the size of a large company is judged by the number of assets owned by the company which can later be used for personal interests by the company's management which complicates supervision which will increase agency costs. According to Yulianti, Agustin, \& Taqwa (2019), audit fees charged to large companies are much higher than small companies because of the higher complexity and require a longer audit time than small companies so that it will affect the company's audit fees. 
Emphasized also by Wiratmaja \& Haryani (2014), large companies do a lot of transactions so that the company is also increasingly complex, and auditors need a lot of time and effort to gather evidence that will strengthen their audit opinion and will have a direct influence on the audit fees charged to the auditees. This research is also in line with the research of Immanuel \& Yuyetta (2014), who found similar results.

\section{The effect of capital structure on agency costs}

Capital structure is represented by debt-to-equity (DER),

Table 9 - Correlation

\begin{tabular}{ccccc}
\hline \multirow{2}{*}{$\mathrm{R}$} & R Square & $\begin{array}{c}\text { Adjusted R } \\
\text { Square }\end{array}$ & $\begin{array}{c}\text { Std. Error of the } \\
\text { Estimate }\end{array}$ & Durbin-Watson \\
\hline 0.175 & 0.031 & 0.013 & 1.18182 & 1.684 \\
\hline & \multicolumn{3}{c}{ Regression Analysis } \\
\cline { 2 - 4 } & Variable & $\begin{array}{c}\text { Unstandardized } \\
\text { Coefficients (B) }\end{array}$ & $\begin{array}{c}\text { Significance } \\
\text { Value }(\alpha=5 \%)\end{array}$ \\
\cline { 2 - 4 } & Capital Structure & $-0,293$ & 0,000 \\
\cline { 2 - 4 }
\end{tabular}

Meanwhile, through the significance value obtained, it was found that agency cost was partially influenced by capital structure with a value of 0.000 as significance values. One of the other factors that can influence agency cost is the capital structure. A company is able to run if it has capital that comes from debt and equity and management are required to be able to manage capital as effectively and efficiently as possible. In this study, it was found that agency cost, which is measured through audit fees, is able to be influenced by the capital structure, which means that management is able to manage capital well. With debt, management will be motivated not to prioritize their own interests through unnecessary expenses so that the company is able to pay off existing debts. The results of this study agree with the research Jensen \& Meckling (1976), where it is explained that debt is a mechanism that supports the principal and agent to unite based on interests and priorities.

\section{The effect of board of commissioner, audit committee, company size, and capital structure on agency costs}

Muliple regression analysis was used in analyzing the data. Correlation, coefficient of determination, and regression are as follows:

\section{Table 10 Correlation}

\begin{tabular}{cccccc}
\hline $\mathrm{R}$ & $\mathrm{R}$ Square & $\begin{array}{c}\text { Adjusted R } \\
\text { Square }\end{array}$ & $\begin{array}{c}\text { Std. Error of } \\
\text { the Estimate }\end{array}$ & $\begin{array}{l}\text { Durbin- } \\
\text { Watson }\end{array}$ & Sig. \\
\hline 0.749 & 0.561 & 0.527 & 0.81817 & 2.222 & 0.000 \\
\hline
\end{tabular}

Meanwhile, the simultaneous correlation test in this study produces a significant value of 0.000 and less than 0.05 (Sig. F change <0.05) so that the four independent variables simultaneously correlate or are related to the dependent variable, namely agency cost as measured by audit fees., with a correlation coefficient value of 0.749 which is considered to have a strong correlation by all independent variables with the dependent variable having a strong relationship or correlation $(\mathrm{R}=0.70-0.90)$. And through this research results found, $\mathrm{H}_{5}$ is accepted where there is an effect simultaneously by the board of commissioners, audit committee, company size, and capital structure on agency cost. 


\section{Multiple Linear Regression Analysis}

Based on the processed data, the results of the regression analysis are as follows:

Table 11 - Hypothesis Test Results

\begin{tabular}{lcc}
\hline \multicolumn{1}{c}{ Variable } & $\begin{array}{c}\text { Unstandardized } \\
\text { Coefficients (B) }\end{array}$ & $\begin{array}{c}\text { Significance } \\
\text { Value }(\alpha=5 \%)\end{array}$ \\
\hline Board of Commissioners & 0.311 & 0.000 \\
\hline Audit Committee & -0.385 & 0.083 \\
\hline Firm Size & 0.687 & 0.000 \\
\hline Capital Structure & -0.293 & 0.000 \\
\hline
\end{tabular}

Through the data analysis carried out, the regression model obtained from the data is as follows:

$A C=0.562+0,311$ BOC $-0,385$ ACOM+0,687 FISI - 0,293 DER +e

\section{CONCLUSIONS AND SUGGESTIONS}

Partially, this research concludes that the composition of the board of commissioners of a company is able to influence the agency costs borne by the company as measured by the audit fee. The increase in company audit fees was followed by an increase in the composition of the board of commissioners, where there was a tendency for a lack of supervision related to management activities. The second variable of this study, namely the audit committee, does not have a significant effect on agency cost. The task of the committee is to help maximize the duties of the board of commissioners. This study concludes that the audit committee is less effective in carrying out its duties to supervise management performance so that it is unable to influence the audit fee.

Company size is one of the factors that can influence the agency costs of the company in this study. The company's audit fee is a variable expense that is determined based on several aspects, one of which is the complexity of the company, a large company is a complex company so that it requires considerable time and audit effort so that it will affect the audit fee charged to the company. And another factor that can trigger agency cost is the capital structure. Companies use capital in the form of debt to carry out their operations, companies with high debt levels encourage management to act carefully in disbursing funds so that actions for personal gain can be minimized and agency costs can be reduced.

And through this research, it is concluded that the board of commissioners, audit committee, company size, and capital structure simultaneously can influence agency cost. And this study suggests companies increase supervision and control by the board of commissioners and audit committee on management activities in order to reduce agency costs. For further researchers, can replace the object of research and develop it on recent objects and develop research through other factors that are deemed capable of influencing agency costs and which have rarely been previously studied.

\section{REFERENCE}

Afriani, A. (2017). Interaksi Konservatisme Conditional dan Income Smoothing (Studi Empiris Pada Perusahaan Manufaktur Yang Terdaftar di Bursa Efek Indonesia Tahun 2010-2015). Jurnal Akuntansi, 5(2), 1-9.

Audinia, N. M. (2017). Pengaruh Dewan Komisaris, Komite Audit, Dan Utang Terhadap Biaya Keagenan (Perusahaan Badan Usaha Milik Negara Go Public Tahun 2003-2016). Doctoral dissertation, Universitas Negeri Semarang.

Ayu, P. P., \& Septiani, T. (2018). Pengaruh Ukuran Dewan Komisaris, Komite Audit, dan KAP 
terhadap Fee Audit Eksternal. Jurnal Akuntansi, 12(1), 1-15.

Badan Pengawas Pasar Modal dan Lembaga Keuangan. (2012). Pembentukan dan Pedoman Pelaksanaan Kerja Komite Audit.

Chandra, M. O. (2015). Pengaruh Good Corporate Governance, Karakteristik Perusahaan Dan Ukuran Kap Terhadap Fee Audit Eksternal. Jurnal Akuntansi Bisnis, XIII(26), 174-194.

Cristansy, J., \& Ardiati, A. Y. (2016). Pengaruh kompleksitas perusahaan, ukuran perusahaan, dan ukuran kap terhadap fee audit pada perusahaan manufaktur yang terdaftar di bei tahun 2012-2016. Modus, 30(2), 198-211.

DeAngelo, L. E. (1981). Auditor Size and Audit Quality. Journal of Accounting and Economics, 3(3), 183-199.

Destriana, N. (2015). "Pengaruh debt to equity ratio, dividen, and faktor non keuangan terhadap agency cost. Jurnal Bisnis Dan Akuntansi, 17(2), 125-133.

Fatahillah, S. (2018). Pengaruh Mekanisme Good Corporate Governance Terhadap Biaya Agensi Pada Perusahaan Manufaktur Yang Terdaftar Di Bursa Efek Indonesia Tahun 2013-2017. Universitas Islam Indonesia.

Godfrey, J., Hodgson, A., Tarca, A., Hamilton, J., \& Holmes, S. (2010). Accounting Theory, 7th Edition. In Accounting Theory.

Gul, S., Sajid, M., Razzaq, N., \& Afzal, F. (2012). Agency cost, corporate governance and ownership structure. International Journal of Business and Social Sciences, 3(9), 268277. Retrieved from http://mpra.ub.uni-muenchen.de/42418/

Hapsari, E. D., \& Laksito, H. (2013). Pengaruh Fungsi Audit Internal Terhadap Fee Auditor Eksternal. Diponegoro Journal of Accounting, 2(2), 1-10.

Harahap, J. A. (2011). Pengaruh Mekanisme Corporate Gorvernance, Ukuran Perusahaan, Dan Kebijakan Hutang. Universitas Islam Negeri Syarif Hidayatullah.

Hartomo, G. (2019, Juni 28). Kronologi Kasus Laporan Keuangan Garuda Indonesia hingga Kena Sanksi . Oke Finance. Diakses dari https://economy.okezone.com/read/2019/06/28/320/2072245/kronologi-kasus-laporankeuangan-garuda-indonesia-hingga-kena-sanksi

Hasan, M. A. (2017). Pengaruh Kompleksitas Audit, Profitabilitas Klien, Ukuran Perusahaan dan Ukuran Kantor Akuntan Publik terhadap Audit Fee. Pekbis Jurnal, 9(3), 214-230.

Hastori, H., Siregar, H., Sembel, R., \& Ahmad Maulana, T. N. (2015). Agency costs, corporate governance and ownership concentration: The case of agro-industrial companies in Indonesia. Asian Social Science, 11(18), 311-319. https://doi.org/10.5539/ass.v11n18p311

Ikatan Akuntan Publik Indonesia. (2016). Peraturan Pengurus Nomor 2 Tahun 2016 Tentang Penentuan Imbalan Jasa Audit Laporan Keuangan (pp. 1-18). pp. 1-18.

Immanuel, R., \& Yuyetta, E. N. A. (2014). Analisis Faktor-Faktor yang Mempengaruhi Penetapan Audit Fees. Diponegoro Journal of Accounting, 3(3), 1-12.

Immanuela, I. (2014). Pengaruh Kepemilikan Manajerial, Struktur Modal, Ukuran Perusahaan, dan Agency Cost sebagai Variabel Intervening terhadap Kinerja Perusahaan pada Perusahaan Manufaktur yang Terdaftar di BEI. Widya Warta: Jurnal Ilmiah Universitas Katolik Widya Mandala Madiun, 38(1), 59-70. Retrieved from http://repository.widyamandala.ac.id/360/

Irwansyah, Lestari, Y., \& Adam, N. F. (2020). Pengaruh ukuran perusahaan dan leverage terhadap agency cost pada perusahaan otomotif yang terdaftar di bursa efek indonesia The effect of company size and leverage on agency cost in automotive companies listed on the Indonesian stock exchange Industri ot. 16(2), 259-267.

Jaelani, M. R. (2017). Pengaruh Kepemilikan Institusional, Kepemilikan Manajerial Dan Struktur Modal Terhadap Agency Costs (Studi pada Industri Logam Yang Listing Di Bursa Efek Indonesia Periode 2013-2015). Universitas Widyatama. 
Jensen, M. C., \& Meckling, W. H. (1976). Theory of the firm: Managerial behavior, agency costs and ownership structure. Journal of Financial Economics. https://doi.org/10.1016/0304-405X(76)90026-X

Krisnauli, \& Hadiprajitno, B. (2014). Pengaruh Profitabilitas Terhadap Kebijakan Hutang. Diponegoro Journal of Accounting, 3(2), 1-13.

Lastian, S. (2015). Analisis Pengaruh Struktur Kepemilikan Dan Mekanisme Corporate Governance Terhadap Agency Cost Pada Perusahaan Perbankan Yang Terdaftar Di Bursa Efek Indonesia Periode 2010-2012. STIE Indonesia Banking School.

Maryam, D. (2018). Pengaruh Struktur Modal dan Ukuran Perusahaan Terhadap Agency Cost dan Kinerja Perusahaan (Studi Pada Perusahaan Manufaktur Sektor Industri Barang Konsumsi Yang Terdaftar Di Bursa Efek Indonesia). Jurnal Akuntansi Dan Pajak, 18(2), 196-203. https://doi.org/10.29040/jap.v18i2.155

Nugroho, D. A. (2017). Pengaruh Karakteristik Komite Audit, Kompensasi Eksekutif Dan Kompleksitas Audit Terhadap Biaya Audit Perusahaan. Doctoral dissertation, Fakultas Ekonomika dan Bisnis, Universitas Diponegoro.

Otoritas Jasa Keuangan Republik Indonesia. (2007). Undang - Undang Republik Indonesia Nomir 40 Tahun 2007 (Vol. 40, pp. 1-140). Vol. 40, pp. 1-140.

Pratiwi, T. A. (2017). Pengaruh Ukuran Dewan Komisaris, Komisaris Independen, Komite Audit dan Anak Perusahaan Terhadap Auditfee (Studi Empiris pada Perusahaan Real Estate and Property yang Terdaftar di Bursa Efek Indonesia Periode 2011-2015). Journal of Accounting, 3(3). https://doi.org/10.1145/3132847.3132886

Pujawati, P., \& Surasni, N. K. (2019). Pengaruh Capital Structure Dan Firm Size Terhadap Agency Cost Dan Kinerja Keuangan. Jurnal Magister Manajemen, 9(1), 78-90. https://doi.org/10.29303/jmm.v9i1.496

Ramadona, A., Tanjung, A. R., \& Rusli. (2016). Pengaruh Struktur Kepemilikan Manajerial, Struktur Kepemilikan Institusional, Ukuran Perusahaan Dan Leverage Terhadap Konvservatisme Akuntansi (Studi pada Perusahaan Makanan dan Minuman yang Terdaftar di Bursa Efek Indonesia Tahun 2011-2014). 3(1).

Romadhoni, \& Sunaryo, H. (2017). Pengaruh Struktur Modal Terhadap Kinerja Keuangan Perusahaan Manufaktur Sektor Makanan dan Minnuman Yang Terdaftar di Bursa Efek Indonesia Tahun 201-2016. Jurnal Ilmiah Riset Manajemen, 6(6), 82-94.

Septiawan, I. K. H., \& Wirawati, N. G. P. (2016). Pengaruh Kepemilikan Asing, Ukuran Perusahaan, Dan Kebijakan Utang Pada Kos Keagenan. E-Jurnal Akuntansi Universitas Udayana, 17(1), 481-508.

Sitompul, F. (2019). Pengaruh Mekanisme Good Corporate Governance dan Karakteristik Perusahaan terhadap Audit Fee Eksternal (Studi Pada Perusahaan Manufaktur Yang Terdaftar Di Bursa Efek Indonesia). Ikraith-Ekonomika, 2(1), 67-76.

Syahrul, Y. (2003, Desember 8). Bapepam: Kasus Kimia Farma Merupakan Tindak Pidana . Tempo.co. Diakses dari https://bisnis.tempo.co/read/33339/bapepam-kasus-kimia-farmamerupakan-tindak-pidana

Sukrisno, A. (2012). Auditing (Petunjuk Praktis Pemeriksaan Akuntan oleh Akuntan Publik) Buku Satu. In Jakarta: Salemba Empat.

Surjawati, Rossyati, \& Widowati, A. I. (2015). Corporate Governance, Struktur Kepemilikan dan Biaya Agensi (Pada Perusahaan LQ 45 Indonesia Tahun 2009 - 2011). Seminar Nasional Hasil Penelitian, 430-440.

Wijayati, F. L. (2015). Analisis Pengaruh Kepemilikan Manajerial , Kepemilikan Institusional , Ukuran Dewan Direksi , Dan Ukuran Dewan Komisaris Terhadap Biaya Keagenan. Jurnal EBBANK, 6(2), 1-16.

Wiratmaja, I. D. N., \& Haryani, J. (2014). Pengaruh Ukuran Perusahaan, Komite Audit, Penerapan Dan International Financial Reporting Standards Dan Kepemilikan Publik Pada 
Audit Delay. E-Jurnal Akuntansi Universitas Udayana, ISSN: 2302-8556, 6(1), 63-78.

Wulandari, E., \& Sutandi. (2018). Analisis Pengaruh Profitabilitas, Financial Leverage, Dan Ukuran Perusahaan Terhadap Income Smoothing ( Studi Empiris Pada Perusahaan Jasa Keuangan Sub Sektor Perbankan Di Bursa Efek Indonesia Periode Analysis of the Effect of Profitability , Financial. Jurnal Ilmiah Akuntansi Dan Teknologi, 10(02), 1-14.

Yulianti, N., Agustin, H., \& Taqwa, S. (2019). Pengaruh Ukuran Perusahaan, Kompleksitas Audit, Risiko Perusahaan, Dan Ukuran Kap Terhadap Fee Audit (Studi Empiris Pada Perusahaan Non Keuangan yang Terdaftar di BEI pada Tahun 2014 - 2017). Jurnal Eksplorasi Akuntnasi, 1(1), 217-235.

Zheng, M. (2013). Empirical Research of the Impact of Capital Structure on Agency Cost of Chinese Listed Companies. International Journal of Economics and Finance, 5(10), 118 125. https://doi.org/10.5539/ijef.v5n10p118 